KS. MICHAŁ SIENNICKI SAC

Papieski Uniwersytet Świętego Krzyża w Rzymie

\title{
DE CONCORDIA INTER CODICES - ZGODA MIĘDZY KODEKSAMI
}

Treść: Wstęp. - 1. Przyczyny promulgacji. - 2. Promulgacja. - 3. Historia powstania De concordia inter Codices. - 4. Adresaci zmian prawnych w szczególnej sytuacji Polski. - 5. Zmiany prawa dokonane przez De concordia inter Codices. - 6. Kościół sui iuris. - 7. Przynależność do Kościoła katolickiego w efekcie chrztu (art. 1). - 8. Moment przynależności do Kościoła sui iuris oraz chrzest dziecka (art. 2-5). - 9. Kapłan i tylko kapłan jako świadek kwalifikowany małżeństwa (art. 6, 8, 9, 11). - 10. Kompetencja Ordynariusza miejsca oraz proboszcza do błogosławienia małżeństwa dwojga narzeczonych należących do Kościoła wschodniego (art. 7). - 11. Małżeństwo dwojga wiernych chrześcijan należących do Kościoła wschodniego nie pozostających w pełnej jedności z Kościołem katolickim (art. 11). - 12. Nadal nierozwiązane kwestie. - Zakończenie.

\section{Wstęp}

Jan Paweł II w historii prawa kanonicznego zapisał się promulgowaniem dwóch kodeksów prawa kanonicznego. Cała ponad dwutysiącletnia historia Kościoła zna tylko 3 kodeksy prawa kanonicznego co jeszcze bardziej uwydatnia fakt, czym było promulgowanie dwóch kodeksów przez jednego papieża. Kodeks Prawa Kanonicznego (KPK) promulgowany w 1983 roku jest efektem długiego procesu odnowy zapoczątkowanego przez Jana XXIII, który wraz ze zwołaniem Soboru Watykańskiego II ogłasza konieczność odnowy prawa kanonicznego. Nie bez przesady Jan Paweł II nazywa Kodeks '83 ostatnią księgą 
Soboru Watykańskiego II¹. Odrobinę w cieniu (patrząc z perspektywy Kościoła łacińskiego) następuje promulgowanie Kodeksu Kanonów Kościołów Wschodnich (KKKW) w 1990 roku, dokonując prezentacji tego nowego Kodeksu w czasie trwania synodu biskupów Jan Paweł II stwierdza, że obydwa kodeksy wraz z konstytucją Pastor Bonus stają się współczesnym Corpus Iuris Canonici². Ogromna praca prawników na całym świece daje całemu Kościołowi dwa kodeksy i już od samego początku ich istnienia staje się jasne, że zdarzają się między nimi niezgodności. Pragnienie zniwelowania tych różnic skłania papież Franciszka do promulgowania motu proprio De concordia inter Codices $^{3}$. Sam tytuł papieskiego dokumentu z łatwością prowadzi myśl wszystkich kanonistów do milowego kamienia kościelnego prawa jakim jest Dekret Gracjana znany jako Concordia discordantium canonum. Autor tego dzieła pragnął uzgodnić prawa całego Kościoła by stworzyć uniwersalny system prawny.

\section{Przyczyny promulgacji}

Można domniemywać, że podobne założenie (uzgodnienie systemu prawnego) posiadał Najwyższy Prawodawca Kościelny pragnąc zharmonizować prawo Kościoła łacińskiego i Kościołów wschodnich. Wyraża to wstęp do teksu m.p. De concordia inter Codices „Mając stałą troskę o harmonię między kodeksami, zdałem sobie sprawę że niektóre punkty nie są całkowicie w harmonii między Kodeksem prawa kanonicznego i Kodeksem kanonów Kościołów wschodnich". Tekst dokumentu potwierdza autonomię kodeksów jako odrębnych norm prawnych, $\mathrm{z}$ drugiej strony ukazuje potrzebę zgodności by podmioty prawa nie ucierpiały w wyniku niezgody między nimi. Jest to szczególnie ważne wyzwanie pastoralne $\mathrm{w}$ dzisiejszych czasach

\footnotetext{
${ }^{1}$ Codex est Concilii et, hoc sensu, est „ultimum documentum Conciliare” quod quidem eius constituet vigorem atque valorem, eius unitatem atque irradiationem. IoAnnes Paulus II, Allocutio ad Episcopos, L'Osservatore Romano 23 listopada 1983.

${ }^{2}$ Insegnamenti di Giovani Paolo II, XIII,2, s. 936-937.

${ }^{3}$ List Apostolski w formie motu proprio De concorida inter Codices, L'Osservatore Romano 16 września 2016. (odtąd Concorida inter Codices).
} 
kiedy mobilność ludzi jest ogromna w efekcie zmian politycznych, ekonomicznych i społecznych. Wierni chrześcijanie, członkowie Kościołów wschodnich są zobowiązani do zachowania własnego rytu w jakimkolwiek miejscu się znajdują, wyraził to Sobór Watykański II w Dekrecie o Katolickich Kościołach wschodnich n. 6 i powtarza KKKW kan. 40\$3, respektując to prawo i obowiązek kompetentna władza kościelna ma obowiązek zapewnić tym wiernym środki do wypełnienia takiego zobowiązania (KPK can. 383\$1-2, KKKW can. 193, adhortacja posynodalna Pastores gregis n. 72). Z pewnością kolejnym argumentem skłaniającym do promulgowania m.p. De concordia inter Codices jest potrzeba znajomości dyscypliny kościelnej w konkretnych warunkach szczególnie w świecie zachodnim który w przeważającym stopniu jest łaciński, potrzeba znalezienia sprawiedliwej równowagi by chronić prawo mniejszości wiernych Kościołów wschodnich żyjących w miejscach gdzie przeważają wierni Kościoła łacińskiego.

Kolejnym argumentem prowadzącym do promulgacji m.p. De concordia inter Codices było pragnienie by lepiej określić relacje z wiernymi należącymi do Kościołów wschodnich nie katolickich, a wiernych tych jest tak wielu na terytorium Kościoła łacińskiego.

Wprost wyrażonym celem dokumentu jest osiągnięcie dyscypliny kościelnej, która może zagwarantować pewność moralną w konkretnym duszpasterskim działaniu.

\section{Promulgacja}

Prawodawca w kan. 7 stwierdza: Ustawa powstaje z chwilą jej promulgowania ${ }^{4}$ Kolejny zaś kanon precyzuje sposób promulgowania ustaw kościelnych. Pierwszy paragraf kan. 8 określa: „Powszechne ustawy kościelna są promulgowane przez zamieszczenie w organie

\footnotetext{
${ }^{4}$ Ustawodawca nie podaje definicji terminu Ustawa. Ogranicza się jedynie do powtórzenia reguły zapisanej już w Dekrecie Gracjana. Por. P. Lombardia, Komentarz do kan. 7, w: Codex Iuris Canonici. Kodeks prawa kanonicznego. Komentarz, red. P. Majer, edycja polska na podstawie wydania hiszpańskiego, Kraków 2011, s. 70 .
} 
urzędowym Acta Apostolicae Sedis, chyba że w poszczególnych przypadkach został przepisany inny sposób promulgowania”. Ten szczególny przypadek ma miejsce przy promulgacji m.p. De concordia inter Codices gdzie stwierdza się w zakończeniu dokumentu, że następuje jego promulgacja przez publikację w L'Osservatore Romano i sukcesywne opublikowanie w organie urzędowym Acta Apostolicae Sedis ${ }^{5}$. Dokument nosi datę 31 maja 2016 roku, jednak sama publikacja w L’Osservatore Romano następuje 16 września 2016 roku. W akcie promulgacji nie określa się daty od kiedy wchodzi w życia. Obowiązuje więc to co przepisane jest w kan. $8 \$ 1$ : „Ustawy uzyskują moc prawną wyłącznie po upływie trzech miesięcy od dnia, którym numer Akt jest oznaczony". Zgodnie z tym prawem List apostolski w formie m. p. De concordia inter Codices zaczął obowiązywać dnia 16 grudnia 2016 roku. Rodzi się pytanie czy w Polsce gdzie L'Osservatore Romano ukazuje się w innej formie niż włoski dziennik L’Osservatore Romano ustawa powszechna weszła do użytku w grudniu 2016 roku? Autor zakłada, że zmiany obowiązują w Kościele powszechnym a więc również w Polsce od dnia 16 grudnia 2016. Co nie zmienia faktu iż zdarza się nieświadomość istnienia De concordia inter Codices. Stąd też celem artykułu jest spopularyzowanie znajomości powszechnego prawa kościelnego.

\section{Historia powstania De concordia inter Codices}

Jak jest to powszechnie wiadome, inicjatorem uzgodnienia i zharmonizowania różnic między kodeksami był papież Benedykt XVI, który już w 2007 roku dał impuls do powstania komisji uzgodnień między kodeksami. Komisja ta zajęła się studiowaniem różnic oraz propozycjami ich uzgodnień płynącymi od wielu specjalistów prawa kanonicznego na całym świecie ${ }^{6}$. Prace te zostały przedstawione w trakcie Komisji Plenarnej Papieskiej Rady ds. Tekstów Prawnych

\footnotetext{
${ }^{5}$ AAS 108(2016), s. 602-606.

${ }^{6} \mathrm{O}$ postępowaniu prac nad harmonizowaniem kodeksów daje świadectwo Nota explicativa quoad kan. 1 KKKW, Por. Communicationes 43(2011), s. 315-316.
} 
w 2012 roku, kiedy to następuje zaaprobowanie tekstu jedenastu propozycji uzgodnień do wprowadzenia w treść kodeksu7.

\section{Adresaci zmian prawnych w szczególnej sytuacji Polski}

Papież Franciszek, motywując promulgowanie De concordia inter Codices, podkreśla aspekt pastoralny wprowadzanych zmian. Adresatami docelowymi zmian prawa są wierni Kościołów wschodnich jednako katolicy i członkowie Kościołów wschodnich niekatolickich. Jednak z całą pewnością do znajomości prawa zobowiązani są duszpasterze a w pierwszej kolejności proboszczowie, którzy muszą otrzymać odpowiednie wsparcie prawno-kanoniczne od organów administracji kościelnej ${ }^{8}$. Poza proboszczami wykonawcą zmian wprowadzonych przez De concordia inter Codices jest ordynariusz miejsca9. Takie zmiany w prawie wydają się być niezwykle aktualne w obecnej sytuacji społeczno politycznej w jakiej znajduje się Polska. Dane z roku 2017 podane przez GUS ukazują setki tysięcy mieszkańców Ukrainy, którzy na stałe zamieszkują w Polsce. Bardzo często ci ludzie w większości ochrzczeni w Kościele greko-katolickim lub Kościele prawosławnym są obecni na niedzielnej Eucharystii w łacińskich świątyniach katolickich. Zauważyć trzeba, że wielu polskich hierarchów zdaje sobie sprawę z tej odpowiedzialności duszpasterskiej ${ }^{10}$. Z całą pewnością obowiązkiem duszpasterzy jest zapewnienie odpowiedniej opieki duszpasterskiej z poszanowaniem prawa Kościoła. Stąd też znajomość oraz właściwe zaaplikowanie De concordia inter Codices jest obowiązkiem wszystkich duszpasterzy.

\footnotetext{
${ }^{7}$ P. Gefaell, Commenti al M.P. De concorida inter Codices, Ius Ecclesiae 29(2017), s. 160 .

${ }^{8}$ Kuria diecezjalna wydział sakramentalny bądź gdy nie jest ustanowiony wydział duszpasterstwa ogólnego. W zgodnie z kan. 469 KPK, gdzie troska duszpasterska Kurii diecezjalnej jest wymieniona przed funkcją administracyjną i władzą sądowniczą.

${ }^{9}$ Por. kan $135, \$ 1-2$.

${ }^{10}$ https://ekai.pl/abp-glodz-w-rozmowie-z-kai-o-wielu-odmianach-polskiego-patriotyzmu/ (dostęp: 5-12-2017). Ostatni akapit wywiadu prezentuje skalę zjawiska tylko na terenie jednej diecezji w Polsce.
} 


\section{Zmiany prawa dokonane przez De concordia inter Codices}

List apostolski w formie m. p. De concordia inter Codices składa się z 11 artykułów które zmieniają wcześniejsze zapisy KPK’83 lub wprowadzają nowe zapisy. Najważniejsze zmiany dotyczą: przynależności do konkretnego Kościoła w wyniku chrztu (art. 1), zmiana sformułowania Kościół obrządkowy na Kościół sui iuris, przejście do innego Kościoła sui iuris (art.2) oraz obowiązek dokonania zapisu w księdze ochrzczonych (art.3), warunki godziwego ochrzczenia dziecka (art. 4 i 5), tylko kapłan ważnie asystuje małżeństwu gdy dwie lub tylko jedna ze stron jest obrządku wschodniego ${ }^{11}$ (art. 6, 8, 11), warunek kiedy ordynariusz miejsca lub proboszcz ważnie błogosławi małżeństwo (art. 7), delegacja świeckiego do błogosławieństwa małżeństwa (art. 9), warunek kiedy można błogosławić małżeństwa wiernych nie katolików (art. 10). Z 11 artykułów należy uznać, że n. 9 nie ma wpływu na sytuację Kościoła w Polsce bowiem nie jest praktykowane delegowanie świeckich do błogosławienia małżeństw. Zdaniem autora najważniejszą zmianą zawierając klauzulę unieważniającą ${ }^{12}$ jest ograniczenie władzy diakona, bowiem tylko kapłan może być świadkiem kwalifikowanym małżeństwa w przypadku kiedy dwie lub tylko jedna ze stron jest wiernym Kościoła wschodniego.

\section{Kościół sui iuris (art. 1-2)}

Pierwszy i drugi artykuł m.p. De concordia inter Codices są dedykowane kwestii sformułowania Kościół sui iuris, pierwsza widoczna zmiana to wprowadzenie korekty sformułowania Kościół obrządkowy na Kościół sui iuris. Zmiana ta nie jest jedynie korektą językową ale jest odpowiedzią na problem identyfikacji konkretnego Kościoła. Identyfikacja ta bowiem nie dokonuje się na podstawie obrządku (sposobu sprawowania liturgii) ale dokonuje się w zgodzie z definicją ujętą w kan. 27 i 28 KKKW. Użycie sformułowania ryt lub obrządek do identyfikacji konkretnego Kościoła nie jest zgodne z rzeczywistością.

\footnotetext{
${ }^{11}$ Tekst włoski używa sformułowania „parte orientale”, czyli należąca do kościoła wschodniego katolickiego lub niekatolickiego.

12 Por. kan. 10.
} 
Może bowiem doprowadzić do pomylenia struktury organizacyjnej z rytem. Konkretny Kościół nie jest bowiem rytem a posiada pewien

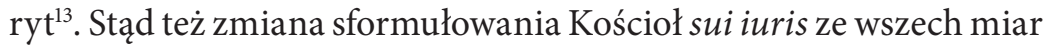
wydaje się zmianą ujawniającą i pomagającą opisać lepiej rzeczywistość. Korekta ta dotyczy kanonów $111 \$ 1$ i\$3, $112 \$ 1$ i $\$ 2$.

W obliczu takiej zmiany pojawia się pewien dość poważny problem interpretacyjny, który został już wcześniej podjęty przez Papieską Radę ds. tekstów prawnych, problem ten koncentruje się w pytaniu: Czy Kościół łaciński jest Kościołem sui iuris w rozumieniu kan. 1 KKKW? Odpowiedź Papieskiej rady zamyka się w nota esplicativa ${ }^{14}$ dotycząca kan. $1 \mathrm{KKKW}^{15}$ zaznaczając jednoznacznie, że nie ma ona wartości interpretacji autentycznej w rozumieniu kan. 16. Nota esplicativa quod can. 1 CCEO stwierdza, że Kościół łaciński jest obejmowany normą prawną ilekroć KKKW używa sformułowania Kościół sui iuris. Oczywiście z zachowaniem analogii prawa bowiem Kościół łaciński tylko w pewnym sensie jest opisany przez kan. 27 i $28 \mathrm{KKKW}^{16}$.

\section{Przynależność do Kościoła katolickiego w efekcie chrztu (art. 1)}

Do kan. 111 m.p. De concordia inter Codices dodaje §2: Jeżeli zaś tylko jedno z rodziców jest katolikiem, zostaje włączone do Kościoła, do którego należy rodzic, który jest katolikiem. Taki dodatek jest odpowiedzią na kan. 29 KKKW. Należy być ostrożnym przy

\footnotetext{
${ }^{13}$ Najlepszym przykładem tego, że Kościół nie jest rytem ale posiada pewien ryt jest Kościół łaciński, który w niektórych częściach świata jak np. w Mediolanie używa rytu Ambrozjańskiego lub w niektórych częściach Hiszpanii rytu Mozarabskiego.

${ }^{14}$ Innym problemem podnoszonym przez kanonistów jest wartość i zasadność wydania noty wyjaśniającej. Papieska rada ds. interpretacji teksów prawnych w swojej kompetencji ma dokonywanie interpretacji autentycznej. Propozycje interpretacji, rozumienia oraz przedstawienie problemów prawnych to rola doktryny.

${ }^{15}$ Communicationes 43(2011), 315-316.

${ }^{16}$ Więcej o zawiłościach tej kwestii prawnej patrz: P. GEFAELL, La correlazione tra CIC'83 e CCEO'90 alla luce della „nota explicativa” del 2011, w: Il diritto canonico orientale a cinquant'anni dal Concilio Vaticano II, Kanonica 22(2016), p. 281-289.
} 
jego interpretacji. Kanon ten wychodzi bowiem naprzeciw problemowi kiedy dziecko ochrzczone jest np. w Kościele prawosławnym ale wychowane w liturgii i tradycji Kościoła katolickiego bo to matka katoliczka była odpowiedzialna za jego religijne wychowanie. Wprowadzając nowy paragraf do kan. 111 Prawodawca dał pewność prawną, że takie dziecko jest członkiem Kościoła katolickiego, chyba, że w zgodzie z paragrafem 3 po ukończeniu 14 roku życia wybrało inny Kościół do którego chce należeć.

\section{Moment przynależności do Kościoła sui iuris oraz chrzest dziecka (art. 2-5)}

Przejście do innego Kościoła sui iuris nie dokonuje się przez nawet długotrwałe przyjmowanie sakramentów według obrzędów innego Kościoła sui iuris. Tak przewiduje kan. $112 \$ 2$ po którym m.p. De concordia inter Codices dodaje \$3: „Każde przejście do innego Kościoła sui iuris osiąga skutek z chwilą złożenia oświadczenia wobec ordynariusza miejsca tego Kościoła albo wobec własnego proboszcza lub delegowanego przez jednego z nich kapłana i dwóch świadków, chyba że reskrypt Stolicy Apostolskiej stanowiłby inaczej; winno być także odnotowane w księdze ochrzczonych".

Dodany paragraf określa jasno moment kiedy zmiana Kościoła sui iuris faktycznie się dokonuje. Nowy tekst dodaje, że taka zmiana powinna być odnotowana w księdze ochrzczonych. Nakłada więc obowiązek na ordynariusza miejsca lub proboszcza do dokonania takiego zapisu lub wydanie odpowiednich pism do parafii w której osoba lub osoby zmieniające przynależność do Kościoła sui iuris, były ochrzczone.

Logiczną konsekwencją kan. $112 \$ 3$ jest korekta w kan. $535 \$ 2$ gdzie prawodawca określa, że także przynależność do Kościoła sui iuris lub przejście do innego muszą być odnotowane w księdze chrztów. Jest to o tyle ważne, że chrzest którego udziela kapłan katolicki, w Kościele katolickim oraz w liturgii łacińskiej nie oznacza, że dziecko automatycznie jest członkiem Kościoła katolickiego łacińskiego. Stąd też potrzeba jasnego zapisu stanu faktycznego, tego czego pragną rodzice. A o czym stanowi art. 5 m.p. De concordia inter Codices wprowadzając 
$\$ 3$ do kan. 868 w brzmieniu: „Dziecko chrześcijan niekatolików jest godziwie ochrzczone, jeśli o to proszą rodzice lub przynajmniej jedno z nich, albo ten, który ich zgodnie z prawem zastępuje, i jeśli fizycznie lub moralnie niemożliwe jest dotarcie przez nich do własnego szafarza". W takim przypadku kapłan katolicki chrzci dziecko w liturgii łacińskiej jednocześnie nie włączając go do Kościoła łacińskiego, stąd też w księdze chrztu musi zostać odnotowany fakt, że dziecko przynależy do innego Kościoła nie mającego jedności z Kościołem katolickim. Prawodawca określa, że taki chrzest jest godziwy jeśli fizycznie lub moralnie niemożliwe jest dotarcie do Kapłana własnego Kościoła niekatolickiego.

\section{Kapłan i tylko kapłan jako świadek kwalifikowany małżeństwa (art. 6, 8, 9, 11)}

Artykuł 6 m.p. De concordia inter Codices dodaje do kan. 1108 trzeci paragraf o treści: $\$ 3$ „Tylko kapłan asystuje ważnie przy zawieraniu małżeństwa między dwiema stronami wschodnimi lub jedną stroną łacińską a drugą wschodnią katolicką bądź niekatolicką". Tak sformułowany zapis kodeksowy zawiera wspomnianą już wcześniej klauzulę unieważniającą $\mathrm{w}$ rozumieniu kan. 10. Ustawa ta zwiera sformułowania mówiące, że do ważności zawieranego małżeństwa potrzeba by asystował kapłan. Oznacza to, że tylko prezbiter lub biskup ważnie błogosławią małżeństwo jeśli jedna ze stron lub dwie są członkami Kościoła wschodniego katolickiego jak i niekatolickiego. Prawodawca wyklucza więc możliwość by to diakon błogosławił takie małżeństwo. Taka zmiana w łacińskim kodeksie odzwierciedla kan. 828 KKKW gdzie do ważności małżeństwa (ad validitatem) wymagany jest święty obrzęd sprawowany przez kapłana. Jest to tradycja Kościołów wschodnich która znajduje swoje uznanie w Katechizmie Kościoła Katolickiego n. $1623^{17}$. Trzeba bowiem pamiętać, że diakoni Kościołów wschodnich nie posiadają władzy błogosławienia stąd

\footnotetext{
${ }^{17}$ KKK 1623: W tradycjach Kościołów wschodnich kapłani lub biskupi, którzy przewodniczą ceremonii, są świadkami wzajemnej zgody wyrażonej przez małżonków, ale ich błogosławieństwo jest konieczne także dla ważności sakramentu.
} 
też nie są zdolni do asystowania i błogosławienia przy zawieraniu małżeństwa. Po wejściu w życie De concordia inter Codices jasnym jest, że małżeństwa pobłogosławione przez diakona gdzie jedna ze stron lub obydwie należą do Kościoła wschodniego są nieważne. Czy nieważne są również takie małżeństwa błogosławione przez diakona przed wejściem w życie De concordia inter Codices (przed 16 grudnia 2016). Pablo Gefaell w artykule komentującym m.p De concordia inter Codices przytacza na ten temat przeróżne opinie kanonistów z całego świata nie zawsze spójne ze sobą ${ }^{18}$. Można więc być wdzięcznym najwyższemu prawodawcy Kościoła, że tak ważną kwestię jednoznacznie wyjaśnił.

Sprawa pozostaje jednak ważna i otwarta. Czy małżeństwa zawarte przed wprowadzeniem m.p. De concordia inter Codices, a pobłogosławione przez diakona są ważne? Wydaje się, że właściwą drogą rozwiązania tej wątpliwości prawnej jest ta zaproponowana prze Pablo Gefaell. Odsyła on do normy prawnej zawartej w kan. 14 KPK oraz 1496 KKKW. Prawodawca określa, że w wątpliwości prawnej ustawy nie obowiązują, nawet unieważniające i uniezdalniające. Przed wprowadzeniem zmian nie było jasne czy małżeństwa błogosławione przez diakona są ważne czy nie. Istniała więc z całą pewnością wątpliwość prawa w myśl kan. 14 KPK. Można więc stwierdzić, że takie małżeństwa zawarte przed 16 grudnia 2016 roku i pobłogosławione przez diakona są małżeństwami ważnymi.

Trzeci paragraf kan. 1108 w logicznej konsekwencji wymaga innych zmian w kodeksie, które Prawodawca wprowadza w tekst KPK'83. Nie zmieniają one prawa a tak jak zostało wspomniane są logiczną konsekwencją paragrafu 3 kan. 1108. Dzieje się tak w kan. 1111 \$1 „Ordynariusz miejsca i proboszcz miejsca, dopóki ważnie sprawują swój

\footnotetext{
${ }^{18}$ Joseph Prader stwierdza, że takie małżeństwa były ważne (por. J. PrAdER, Il matrimonio in Oriente e in Occidente, $2 a$ ed., Roma, PIO, 2003 (Kanonicam, 1), s. 266), jednakże Dimitri Salachas i inni stwierdzali przeciwnie (por. D. SALACHAS K. Nitkiewicz, Inter-Ecclesial Relations between Eastern and Latin Catholics: A Canonical-Pastoral Handbook, angielska wersja w edycji George Dimitry Gallaro, Washington DC, CLSA, 2009, s. 29)
} 
urząd, mogą delegować kapłanom i diakonom uprawnienie - również ogólne - do asystowania przy zawieraniu małżeństw w granicach swego terytorium, z zachowaniem przepisu kan. 1108 \$ 3”. Podobnie ma to miejsce w nowo brzmiącym kan. $1112 \$ 1$ : „Gdzie nie ma kapłanów i diakonów, biskup diecezjalny, uzyskawszy - po wcześniejszej pozytywnej opinii konferencji biskupów - zezwolenie Stolicy Apostolskiej, może delegować świeckich do asystowania przy zawieraniu małżeństw, z zachowaniem przepisu kan. 1108 \$ 3”. Jak zostało już to wcześniej powiedziane kanon ten nie ma zastosowania w polskim duszpasterstwie. Ostatnią zmianą będącą logiczną konsekwencją kan. $1108 \$ 3$ jest kan. 1127: „Co do formy małżeństwa mieszanego, należy zachować przepisy kan. 1108; jeżeli jednak małżeństwo zawiera strona katolicka ze stroną niekatolicką obrządku wschodniego, kanoniczna forma zawarcia wymagana jest tylko do godziwości; do ważności zaś konieczny jest udział kapłana, z zachowaniem innych wymogów prawa".

\section{Kompetencja Ordynariusza miejsca oraz proboszcza do błogosławienia małżeństwa dwojga narzeczonych należących do Kościoła wschodniego (art. 7)}

Problem kompetencji do błogosławienia małżeństwa dwojga narzeczonych należących do Kościołów wschodnich wynikał z trudnej do interpretacji klauzuli kończącej kan. 1109. Zgodnie ze starym zapisem tego kanonu do ważności małżeństwa wymaga się by przynajmniej jeden z nupturientów należał do obrządku łacińskiego, jeśli bowiem oboje należą do katolickiego obrządku wschodniego, będą miały zastosowanie normy KKKW ${ }^{19}$. Nowe brzmienie kan. 1109 KPK w języku łacińskim ${ }^{20}$ dostosowuje się do brzmienia kan. $829 \$ 1 \mathrm{KKKW.}$

\footnotetext{
${ }^{19}$ Por. R. Navarro Valls, Komentarz do kan. 1109 w: Codex Iuris Canonici. Kodeks prawa kanonicznego. Komentarz., red. P. Majer, edycja polska na podstawie wydania hiszpańskiego, Kraków 2011, s. 836.

${ }^{20}$ Jak zauważa Pablo Gefaell wydanie m.p. De Concordia Inter Codices w języku włoskim zawiera błąd umieszczając klauzulę unieważniającą na końcu zdania w ten sposób powodując, że sytuacja prawna się nie zmienia. Co oczywiście jest sytuacją absurdalną. Jak zawsze punktem odniesienia musi być tekst łaciński.
} 
W konsekwencji ordynariusz miejsca oraz proboszcz są kompetentni, w obrębie swojego terytorium, do błogosławienia małżeństwa dwojga wiernych należących do Kościołów orientalnych jeśli są ich poddanymi w rozumieniu kan. $100 \mathrm{KPK}$. Ordynariusz miejsca lub proboszcz byliby niekompetentni do błogosławienia w przypadku: a) kiedy tacy nupturienci nie mają zamieszkania stałego lub tymczasowo w obrębie ich kompetencji terytorialnej, b) na danym terytorium istnieje hierarchia Kościoła wschodniego do którego należą nupturienci, c) jest ustanowiony Ordynariat dla wiernych Kościołów wschodnich z wyłączną jurysdykcją.

\section{Małżeństwo dwojga wiernych chrześcijan należących do Kościoła wschodniego nie pozostających w pełnej jedności z Kościołem katolickim (art. 10)}

Do kan. 1116 KPK, który reguluje przypadki, w których można uciec się do zastosowania formy nadzwyczajnej małżeństwa m. p. De concordia inter Codices dodaje, $1116 \$ 3$ : „W okolicznościach, o których mowa w $\$ 1$ nn. 1 i 2, ordynariusz miejsca może udzielić każdemu kapłanowi katolickiemu uprawnienia do błogosławienia małżeństwa wiernych Kościołów wschodnich, niepozostających w pełnej wspólnocie z Kościołem katolickim, jeżeli ci dobrowolnie o to prosza i jeżeli nic nie stoi na przeszkodzie ważnemu i godziwemu zawarciu małżeństwa. Tenże kapłan, zachowując zawsze konieczną roztropność, winien poinformować o tym właściwą władzę zainteresowanego Kościoła niekatolickiego".

Do właściwego zastosowania tego nowego zapisu kodeksowanego należy zwrócić uwagę na sformułowanie: jeśli spontanicznie o to pro$s z a$. Sformułowanie znane z kanonów KPK’83, które określa zasady Communio in sacris, kiedy katolicki kapłan może ważnie i godziwie udzielić sakramentów spowiedzi, Eucharystii, namaszczenia chorych wiernym należącym do Kościołów nie mającym pełnej jedności z Kościołem katolickim²1.

\footnotetext{
${ }^{21}$ Kan. $884 \$ 3$ Szafarze katoliccy godziwie udzielają sakramentów pokuty, Eucharystii i namaszczenia chorych członkom Kościołów wschodnich nie mających pełnej wspólnoty z Kościołem katolickim, gdy sami o nie proszą i są odpowiednio
} 
W kan. 833 KKKW dodany jest jeszcze inny warunek, błogosławienie małżeństwa dwojga wiernych niekatolików wschodnich jest niemożliwe jeśli nupturienci bez przeszkód mogą się udać do własnego kapłana. Brak takiego zapisu w m.p. De concordia inter Codices. Uprawnienie do błogosławienia takiego małżeństwa ordynariusz miejsca może wystawić jeśli wierni o to proszą i nic nie stoi na przeszkodzie ważnemu i godziwemu zawarciu małżeństwa. Jednakże okoliczność niemożliwości zwrócenia się do własnego kompetentnego szafarza wydaje się być w sposób logiczny włączona w normę kan. $1116 \$ 3$. Wynika to z kontekstu normy, kanon 1116 traktuje bowiem o sytuacji nadzwyczajnej w której wierny nie może zwrócić się do kapłanów Kościoła do którego należy. Kolejnym argumentem powinna być zdrowa wrażliwość duszpasterska i ekumeniczna. W sytuacji kiedy kapłan katolicki rozpocząłby błogosławienie małżeństwa wiernych Kościołów wschodnich. Takie działanie bez należytej roztropności mogłoby mieć negatywne konsekwencje w dialogu ekumenicznym prowadzonym $\mathrm{z}$ wielkim trudem od wielu lat.

Pablo Gefaell przedstawia swój punkt widzenia w następujący sposób. W sytuacji przewidzianej przez prawodawcę w kan. $1116 \$ 3$ tak naprawdę kapłan katolicki znajduje się w obliczu małżeństwa ważnie zawartego, jak to przewiduje forma nadzwyczajna małżeństwa. A wierni Kościoła wschodniego nie mającego pełnej jedności z Kościołem katolickim, zwracają się do kapłana katolickiego, by takie małżeństwo pobłogosławił. Argumentem do takiego zinterpretowania prawa jest klauzula „jeśli nic nie stoi na przeszkodzie ważnemu i godziwemu zawarciu małżeństwa”. Kapłan katolicki błogosławi tylko takie małżeństwo, które może być ważnie i godziwie zawarte

przygotowani. Odnosi się to także do członków innych Kościołów, które według oceny Stolicy Apostolskiej, gdy idzie o sakramenty, są w takiej samej sytuacji, a i wspomniane Kościoły wschodnie.

Więcej o Communicatio in sacris w kontekście prawosławnym zobacz: G. Ruyssen, Il decreto conciliare Unitatis Redintegratio e la sua incidenza sulla communicatio in sacris con gli ortodossi. Evoluzione della disciplina, w: Il diritto canonico orientale a cinquant'anni dal Concilio Vaticano II, Kanonica 22(2016), p. 63-122. 
według normy Kościoła wschodniego nie mającego pełnej jedności z Kościołem katolickim.

Bardzo ciekawym zapisem jest zdanie kończące nowy paragraf kan. 1116. Kapłan, który przez ordynariusza miejsca został wydelegowany do pobłogosławienia takiego małżeństwa, zachowując zawsze konieczną roztropność, winien poinformować o tym właściwą władzę zainteresowanego Kościoła niekatolickiego. Nakaz ten nie jest bezwzględny, zakłada bowiem możliwość, że roztropne rozeznanie kapłana, na którym spoczywa obowiązek przekazania takiej informacji, doprowadzi do podjęcia decyzji przeciwnej. Nie poinformowanie władzy zainteresowanego Kościoła niekatolickiego. Powodem takiej decyzji może być świadomość, że zainteresowana władza Kościoła niekatolickiego nie uzna ważności małżeństwa. By nie wzbudzać wątpliwości sumienia zainteresowanych nupturientów. Prawodawca przewiduje taką możliwość. Zakładając jednak, że normą jest przekazanie informacji o zawartym sakramencie małżeństwa.

\section{Nadal nierozwiązane kwestie}

Zmiany wprowadzone przez m.p. De concordia inter Codices nie łagodzą wszystkich różnic między prawodawstwem Kościoła łacińskiego i Kościołów wschodnich. Jednym z klasycznych przykładów różnic między kodeksami jest kwestia małżeństwa celebrowanego pod warunkiem. Kanon 1102 KPK określa, że jest dopuszczalne zawarcie małżeństwa pod warunkiem dotyczącym przeszłości lub teraźniejszości. Kodeks prawa kanonicznego Kościołów wschodnich w zupełności wyklucza zawarcie małżeństwa pod jakimkolwiek warunkiem, określa to kan. $826 \mathrm{KKKW}$.

KKKW i KPK prezentują odmienne podejście do administracji nadzwyczajnej dóbr kościelnych. Niektórzy autorzy zauważają, że to Kodeks wschodni pozostał spóźniony w swojej legislacji w porównaniu do Kodeksu łacińskiego ${ }^{22}$.

\footnotetext{
${ }^{22}$ Por. L. SAbBarese, L'amministrazione straordinaria dei beni ecclesiastici nel CCEO: un aggiornamento mancato, w: Il diritto canonico orientale a cinquant'anni dal Concilio Vaticano II, Kanonica 22(2016), p. 231-248.
} 
Inna różnica pomiędzy Kodeksami, która nadal pozostaje widoczna to przejście zakonnika do innego instytutu życia konsekrowanego bądź do stowarzyszenia życia apostolskiego. Jednakże różnice te są wynikiem różnych tradycji Kościoła łacińskiego i Kościołów wschodnich ${ }^{23}$.

\section{Zakończenie}

List apostolski w formie motu proprio De concordia inter Codices z całą pewnością jest bardzo delikatną kwestią. Dotyka bowiem w sposób bezpośredni dialogu ekumenicznego. Z drugiej zaś strony dotyczy kwestii duszpasterstwa wiernych, którzy proszą o możliwość życia sakramentalnego w miejscu, w którym aktualnie się znajdują. Pierwszym i najważniejszym zadaniem Kościoła jest sprawowanie sakramentów w sposób ważny i godziwy. Najwyższy Prawodawca Kościelny, zdając sobie sprawę z aktualnych trudności wynikających z dysharmonii między kodeksami, zdecydował się na interwencję w celu uzgodnienia różnic. Należy sobie życzyć, że prawo Kościoła przestrzegane i właściwie aplikowane będzie z pożytkiem dla wszystkich wiernych i dla zbudowania jedności Kościoła.

\section{"De concordia inter Codices" - modifying some norms of the Code of Canon Law}

The following article attempts to explain the reasons why the Supreme Legislator of the Church has decided to promulgate the apostolic letter in the form of a motu proprio, De concorida inter Codices. It presents a brief history of the preparation of the text and the problems concerning its promulgation, both for the universal Church and in the particular case of Poland. The author of the article tries to show the need for knowledge of the new canonical norm already desired by Pope Benedict and finally promulgated by Pope Francis. Canonical science cannot be limited only to

\footnotetext{
${ }^{23}$ Temat ten i odmienne tradycje Kościoła łacińskiego i Kościołów wschodnich przedstawia: C. BALEANI, I requisiti di attuabilità dell' istituto giuridico del passaggio: il principio generale e il consenso, Commentarium pro Religiosis et Missionariis 80(1990), s. 128-154.
} 
the Latin code but must go beyond this to the Eastern code, especially when it comes to matters of marriage and its validity, the sacrament of baptism and enrolment in a Church sui iuris. These are indispensable elements of canonical science that every pastor of the Church must possess and especially those who meet the Eastern faithful in their pastoral circumstances. It is to be hoped that canonical science will help to give pastoral care to all the faithful who await it.

SŁowa KLUCzowe: Kościół sui iuris; Kodeks Kościołów Wschodnich; małżeństwo w Kościele wschodnim; troska pastoralna; De concorida inter Codices

KeYwords: Church sui iuris; Eastern code; marriage in Eastern code; pastoral care; De concorida inter Codices

\section{Nota o Autorze:}

Ks. Micha£ SienNicki SAC - doktorant Papieskiego Uniwersytetu Świętego Krzyża w Rzymie. 